\title{
Trends in the Treatment Outcomes and Features of Cryptorchidism in Boys: A Single-Institute Experience
}

This article was published in the following Dove Press journal: Research and Reports in Urology

\section{Shunta Hori (iD \\ Katsuya Aoki \\ Nobutaka Nishimura (D) \\ Yosuke Morizawa (D) \\ Daisuke Gotoh (D) \\ Shinji Fukui $\mathbb{D}$ \\ Yasushi Nakai \\ Makito Miyake \\ Kazumasa Torimoto (ID \\ Kiyohide Fujimoto}

Department of Urology, Nara Medical University, Kashihara, Nara 634-8522, Japan
Correspondence: Kiyohide Fujimoto Department of Urology, Nara Medical University, 840 Shijo-cho, Kashihara, Nara 634-8522, Japan

Tel +8I-744-22-305I

Fax +81-744-22-9282

Email kiyokun@naramed-u.ac.jp
Purpose: Cryptorchidism is one of the most common congenital abnormalities in pediatric urology, and orchiopexy is performed for the prevention of testicular damage and malignant transformation. We examined the distribution and outcomes of cryptorchidism under a single investigator at our institute.

Patients and Methods: This retrospective study included 283 boys diagnosed with cryptorchidism at our institute. Cryptorchidism was diagnosed based on the medical history and physical examination findings. Boys without spontaneous resolution after 6 months of age were indicated for orchiopexy. We investigated the 12-year trend in the distribution and outcomes of cryptorchidism at the institute.

Results: The mean age at diagnosis, gestational age, and birth weight were 2 years, 37 weeks, and $2740 \mathrm{~g}$, respectively. A total of 170 boys underwent orchiopexy under 2 years of age, and 136 boys underwent orchiopexy under the age of 1 year, while 62 boys underwent orchiopexy over the age of 3 years. Abnormalities of the epididymis and disclosure of the processus vaginalis were observed in $44(25 \%)$ and 72 boys (41\%), respectively. Comparison of boys with or without hypospadias showed that the age at orchiopexy was higher in boys with hypospadias than in those without hypospadias $(\mathrm{P}=0.028)$. In addition, boys without hypospadias had a higher rate of abnormality of the epidermis than those with hypospadias $(\mathrm{P}=0.024)$.

Conclusion: Our findings suggest that most boys with cryptorchidism are treated under the age of 2 years and the incidence of epididymal abnormality is relatively high, especially in boys with hypospadias. An understanding of the natural features of cryptorchidism could lead to better management and outcomes. Further research is warranted to develop an appropriate treatment timeline in boys with cryptorchidism.

Keywords: cryptorchidism, hypospadias, orchiopexy, pediatrics, spontaneous resolution

\section{Introduction}

Cryptorchidism is one of the most common congenital abnormalities in pediatric urology and is defined as a condition in which the testis incompletely descends into the proper scrotal position, resulting in it being located anywhere between the abdominal cavity and the upper scrotum. The incidence rate is reported to be $2-9 \%$ at birth, and some boys have spontaneous resolution by the age of 3-6 months. ${ }^{1-4}$ Testicular descent is a complex and still unclear morphological process induced by at least two stages. The first stage is controlled by insulin-like peptide, ${ }^{3}$ which facilitates gubernacular enlargement, and the second stage is controlled by androgen-facilitating 
inguinoscrotal migration. ${ }^{4,5}$ Therefore, various factors affecting these processes, including genetic and environmental components, can be risk factors. Gestational age, birth weight, family history, complications, and maternal smoking during pregnancy are well-known risk factors. ${ }^{6-9}$ In addition, it is well known that cryptorchidism is a risk factor for both testicular cancer and infertility in adulthood. ${ }^{9}$ Therefore, urologists and pediatricians need to diagnose accurately and provide appropriate timely treatment for boys with cryptorchidism.

Orchiopexy is the standard treatment for cryptorchidism. The main aim of orchiopexy is the prevention of testis deterioration caused by a high thermal environment. This is because hypogonadotropic hypogonadism and exposure to higher temperatures are reportedly involved in the disturbed fertility of cryptorchidism. ${ }^{10,11}$ Histological analysis of cryptorchidism has shown that the testes are progressively damaged over time. ${ }^{12}$ However, whether orchiopexy results in a decreased incidence of testicular cancer remains controversial. A recent study from Sweden, comprising 16,983 patients, suggested that treatment for cryptorchidism before puberty decreased the risk of testicular cancer. ${ }^{13,14}$ Although the optimal timing of orchiopexy remains controversial, in most institutes in Japan, including our institute, orchiopexy is performed until at least 2 years of age.

In this study, we aimed to investigate the distribution, outcomes, and features of cryptorchidism in patients treated at our institute by a single investigator. An understanding of the prevalence of cryptorchidism, outcomes including spontaneous resolution and surgical intervention, and features such as the relationship with hypospadias can lead to better management and strategies.

\section{Patients and Methods Study Cohort and Data Collection}

The inclusion criteria were boys who were diagnosed with cryptorchidism at our institute and the exclusion criteria were boys for whom clinical data were insufficient retrospectively. The study flowchart is shown in Figure 1. A total of 283 Japanese boys were diagnosed with cryptorchidism at our institute between January 2006 and December 2017. Of 283 boys, 23 boys (8.1\%) were excluded from this study because the baseline clinical data or follow-up data were missing. Subsequently, boys

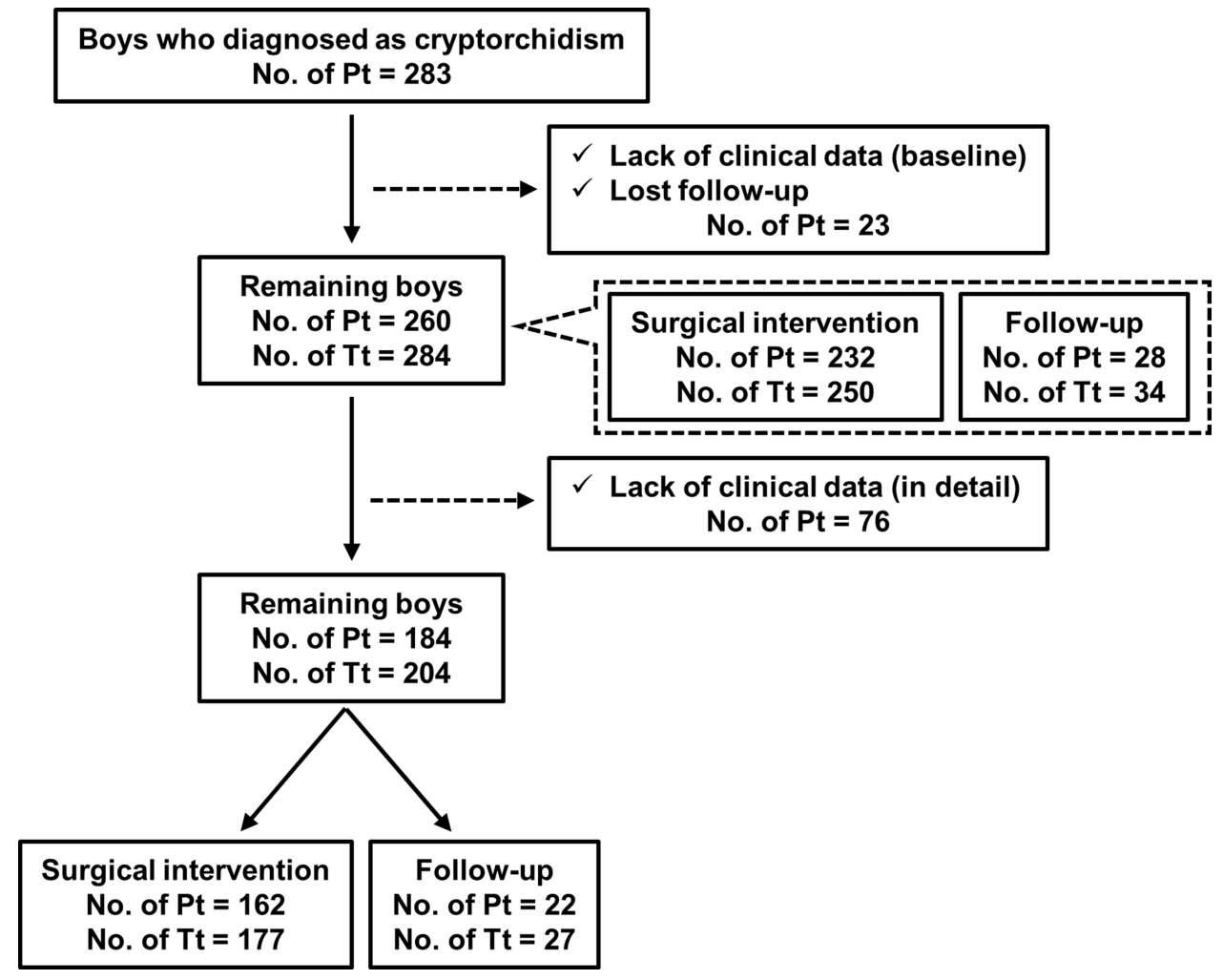

Figure I Study flow. A total of 283 boys were diagnosed with cryptorchidism between January 2006 and December 2017 at our institute. Twenty-three boys were excluded owing to the lack of baseline data or follow-up data. The remaining 260 boys were investigated in this study. Of the 260 boys, 232 underwent orchiopexy. Of the 260 boys, 76 boys were additionally excluded because of the lack of detailed data. A detailed investigation was conducted for the remaining 184 boys.

Abbreviations: No, number of; Pt, patient; Tt, testis. 
without detailed clinical data were excluded $(\mathrm{n}=76$ [26.9\%]) and data of the remaining 184 boys $(65.0 \%)$, including 204 testes, were investigated retrospectively in this study. Clinical characteristics including age, gestational period, birth weight, follow-up period, location of testis, surgical information, and outcomes were all obtained from medical charts. None of the boys underwent hormonal therapy. The main outcome of this retrospective study was the feature of treatment, especially orchiopexy, in Japanese boys.

\section{Ethics Approval and Consent to Participate}

This study was conducted in compliance with the study's protocol and following the provisions of the Declaration of Helsinki (2013) and was approved by the research ethics committee of Nara Medical University (project identification code: 2630). The requirement for informed patient consent was waived because of the retrospective nature of the analysis. Personal information linked to research subjects and donors was anonymized (when necessary, the information was labeled with an identifying code to make it possible to distinguish between the individuals). Then, deidentified patient data were analyzed.

\section{Diagnosis and Orchiopexy}

The diagnosis and treatment plan were conducted by a single investigator (K.A.) who had expertise in pediatric urology. Cryptorchidism was diagnosed based on the medical history and findings of the physical examination and imaging tests, including ultrasonography or magnetic resonance imaging, if necessary. Cryptorchidism was defined when a testis is not at the bottom of the scrotum but at the upper scrotum, in the inguinal canal, or in the intraperitoneal, and a testis cannot be manually descended to the bottom of the scrotum and returned to the original position immediately. Generally, cryptorchidism was classified into palpable and non-palpable testes, and the surgical procedure for cryptorchidism was determined based on this information. Orchiopexy was performed after the age of six months because previous reports showed that cryptorchidism rarely descended after the age of three to six months. ${ }^{1,2}$ Resolution and termination of follow-up were defined when a testis has descended into the scrotum spontaneously or by orchiopexy.

\section{Statistical Analysis}

Statistical analyses were performed and figures were plotted using GraphPad Prism 7.0 (GraphPad Software, San Diego, CA, USA). Student's $t$-test or the MannWhitney $U$-test was used for statistical analysis. Twosided tests were used in all cases, and a $\mathrm{P}$ value $<0.05$ was considered statistically significant in all analyses.

\section{Results}

\section{Characteristics of the Cohort}

Table 1 shows the clinical characteristics of the cohort of 184 boys for whom detailed clinical data were available. The mean age at diagnosis, gestational age, and birth weight were 2 years (range 0-9), 37 weeks (range 23-42), and $2740 \mathrm{~g}$ (range 622-4812), respectively. Of 184 boys, 72 cases (39\%) were consulted at our institute following a health examination for the baby. There were 164 boys $(89 \%)$ with unilateral cryptorchidism (right side, 75 boys [41\%]; left side, 89 boys [48\%]) and 20 boys $(11 \%)$ with bilateral cryptorchidism. Of 184 boys, 131 boys, including 143 testes, were diagnosed with palpable testes. The testicular location of 143 palpable testes were as follows: 23 testes $(15 \%)$ were located at the upper scrotum, 115 testes $(81 \%)$ were located in the inguinal canal, and 5 testes (4\%) were of an unknown location. With regard to complications, there were 13 (7\%), $9(5 \%), 13(7 \%), 2(1 \%)$, and $12(6 \%)$ cases of hydrocele, inguinal hernia, hypospadias, micropenis, and contralateral retractile testis, respectively. The mean follow-up period was 36 months (range $0-145$ ). Eventually, orchiopexy was performed in 162 boys $(88.0 \%$; 177 testes $[86.7 \%])$, the condition improved spontaneously in 12 boys $(6.5 \% ; 14$ testes [6.9\%]), and 10 boys $(5.5 \% ; 13$ testes $[6.4 \%])$ were being followed up at the last observation date in this study.

\section{Features of Boys Who Underwent Orchiopexy}

Table 2 shows the clinical characteristics of the cohort of 162 boys who underwent orchiopexy and had available detailed clinical data. The mean age, height, and weight at orchiopexy were 1 year (range 0-9), $79.3 \mathrm{~cm}$ (range, 48.0-130.0), and $11.1 \mathrm{~kg}$ (range, 2.8-28.0), respectively. The surgical procedures were divided into 4 groups: scrotal (4 boys, $2 \%$ ), inguinal $(77,48 \%)$, laparoscopic $(4,2 \%)$, and both laparoscopic and inguinal $(17,11 \%)$. Preoperative testicular atrophy was observed in 18 testes $(10 \%)$. During 
Table I Characteristics of I84 Boys with Cryptorchidism

\begin{tabular}{|c|c|c|c|}
\hline \multicolumn{2}{|l|}{ Variables } & \multirow{2}{*}{$\begin{array}{l}\text { Number of Boys } \\
2(0-9)\end{array}$} & \multirow{2}{*}{$\%$} \\
\hline Age at diagnosis (years) & Mean (range) & & \\
\hline Gestational age (weeks) & Mean (range) & $37(23-42)$ & - \\
\hline Birth weight (g) & Mean (range) & $2740(622-48 \mid 2)$ & - \\
\hline \multirow[t]{3}{*}{ Diagnostic opportunity } & & & \\
\hline & Health examination for baby & 72 & 39 \\
\hline & Incidental & 112 & 61 \\
\hline \multirow[t]{3}{*}{ Family history } & & & \\
\hline & No & 180 & 98 \\
\hline & Yes & 4 & 2 \\
\hline \multirow[t]{4}{*}{ Side } & & & \\
\hline & Right & 75 & 41 \\
\hline & Left & 89 & 48 \\
\hline & Bilateral & 20 & II \\
\hline \multirow[t]{3}{*}{ Palpable (204 testes) } & & & \\
\hline & No & 61 & 30 \\
\hline & Yes & 143 & 70 \\
\hline \multirow[t]{4}{*}{ Location (I43 palpable testes) } & & & \\
\hline & High scrotal & 23 & 15 \\
\hline & Canalicular & 115 & 81 \\
\hline & Unknown & 5 & 4 \\
\hline \multirow[t]{6}{*}{ Complications } & & & \\
\hline & Hydrocele & 13 & 7 \\
\hline & Inguinal hernia & 9 & 5 \\
\hline & Hypospadias & 13 & 7 \\
\hline & Micropenis & 2 & I \\
\hline & Contralateral retractile testis & 12 & 6 \\
\hline Follow-up period (months) & Mean (range) & $36(0-145)$ & - \\
\hline \multirow[t]{4}{*}{ Treatment option } & & & \\
\hline & Orchiopexy & 162 & 88 \\
\hline & Spontaneous resolution & 12 & 7 \\
\hline & Under follow-up & 10 & 5 \\
\hline
\end{tabular}

orchiopexy, abnormality of the epididymis and closure of the processus vaginalis were observed in 44 (25\%) and 24 boys $(13 \%)$, respectively, based on the available data. The Fowler-Stephens method was used for 8 testes (5\%) located intra-abdominally. The gonadal artery was cut in all 8 testes, and of the 8 testes, 4 were treated in two steps, and the remaining 4 testes were treated in one step. During orchiopexy, 6 testes were vanishing testes and 18 testes were resected because of nubbin. In addition, there was no perioperative complication. Eventually, there was no testis reelevation, and testicular atrophy was observed in 1 testis after orchiopexy.

\section{Comparison of Characteristics Between Boys Who Underwent Orchiopexy and Boys Improved Spontaneously}

In the cohort of 184 boys who had available detailed data, 162 boys underwent orchiopexy, the condition in 12 boys improved spontaneously, and 10 boys were under observation. To investigate the differences in characteristics between boys who underwent orchiopexy and boys in whom the condition improved spontaneously, 162 and 12 boys were compared. Table 3 shows the clinical characteristics of the cohort of 174 
Table 2 Surgical Information $(n=162)$

\begin{tabular}{|c|c|c|c|}
\hline \multicolumn{2}{|l|}{ Variables } & \multirow{2}{*}{$\begin{array}{l}\text { Number of Boys } \\
162\end{array}$} & \multirow{2}{*}{$\begin{array}{l}\% \\
100\end{array}$} \\
\hline Number of patients & & & \\
\hline Age at orchiopexy (years) & Mean (range) & I (0-9) & - \\
\hline Height at orchiopexy $(\mathrm{cm})$ & Mean (range) & $79.3(48.0-130.0)$ & - \\
\hline Weight at orchiopexy (kg) & Mean (range) & II.I (2.8-28.0) & - \\
\hline \multirow[t]{6}{*}{ Approach } & & & \\
\hline & Scrotal & 4 & 2 \\
\hline & Inguinal & 77 & 48 \\
\hline & Laparoscopic & 4 & 2 \\
\hline & Laparoscopic+Inguinal & 17 & 11 \\
\hline & Unknown & 60 & 37 \\
\hline \multirow[t]{3}{*}{ Side } & & & \\
\hline & Unilateral & 147 & 91 \\
\hline & Bilateral & 15 & 9 \\
\hline \multirow{3}{*}{$\begin{array}{l}\text { Testicular atrophy } \\
\text { (177 testes) }\end{array}$} & & & \\
\hline & No & 159 & 90 \\
\hline & Yes & 18 & 10 \\
\hline \multirow{3}{*}{$\begin{array}{l}\text { Abnormality of epididymis } \\
\text { (177 testes) }\end{array}$} & & & \\
\hline & No & 133 & 75 \\
\hline & Yes & 44 & 25 \\
\hline \multirow{4}{*}{$\begin{array}{l}\text { Closure of processus vaginalis } \\
\text { (177 testes) }\end{array}$} & & & \\
\hline & No & 72 & 41 \\
\hline & Yes & 24 & 13 \\
\hline & Unknown & 81 & 46 \\
\hline \multirow[t]{2}{*}{$\begin{array}{l}\text { Testicular gubernaculum attachment } \\
\text { (177 testes) }\end{array}$} & Upper scrotum & 150 & 85 \\
\hline & Inguinal canal & 27 & 15 \\
\hline Use of Fowler-Stephens method & By one step & 4 & 2 \\
\hline (I77 testes) & By two steps & 4 & 2 \\
\hline \multirow{5}{*}{$\begin{array}{l}\text { Outcomes } \\
\text { (177 testes) }\end{array}$} & & & \\
\hline & Vanishing testis & 6 & 4 \\
\hline & Orchiectomy & 18 & 10 \\
\hline & Re-elevation & 0 & 0 \\
\hline & Testicular atrophy & I & 1 \\
\hline
\end{tabular}

boys. There was no significant difference in the age at diagnosis, gestational age, or birth weight between the two groups $(\mathrm{P}=0.41, \mathrm{P}=0.40$, and $\mathrm{P}=0.10$, respectively). All boys who exhibited spontaneous improvement were diagnosed with cryptorchidism incidentally $(\mathrm{P}=0.017)$. In addition, there were no differences in the side, palpation, and location of the testis between the two groups $(\mathrm{P}=0.33, \quad \mathrm{P}=0.53$, and $\mathrm{P}=0.31$, respectively).

\section{Comparison of Characteristics Between Cryptorchidism without Hypospadias and with Hypospadias}

In the cohort of 184 boys who had available detailed data, 13 boys were concomitant with hypospadias. To investigate the difference in characteristics between boys without and with hypospadias, 171 and 13 boys were compared. Table 4 shows the clinical characteristics of the cohort of 184 boys. There was no difference in the age at diagnosis 
Table 3 Comparison of Characteristics Between Boys Who Underwent Orchiopexy and Boys Improved Spontaneously ( $\mathrm{n}=$ I74)

\begin{tabular}{|c|c|c|c|c|}
\hline \multicolumn{2}{|l|}{ Variables } & \multicolumn{2}{|l|}{ Resolution } & \multirow[t]{3}{*}{$P$ value } \\
\hline & & \multirow{2}{*}{$\begin{array}{l}\text { By Orchiopexy } \\
162\end{array}$} & \multirow{2}{*}{$\begin{array}{l}\text { Spontaneously } \\
12\end{array}$} & \\
\hline Number of patients & & & & \\
\hline Age at diagnosis (years) & Mean (range) & $0(0-9)$ & $0(0-2)$ & 0.41 \\
\hline Gestational age (weeks) & Mean (range) & $38(23-42)$ & $36(23-4 I)$ & 0.4 \\
\hline Birth weight (g) & Mean (range) & $2780(622-48 \mid 2)$ & $2375(624-3778)$ & 0.1 \\
\hline Follow-up period (months) & Mean (range) & $10(0-27)$ & $8(0-18)$ & 0.93 \\
\hline Diagnostic opportunity & $\begin{array}{l}\text { Health examination for baby } \\
\text { Incidental }\end{array}$ & $\begin{array}{l}71 \\
91\end{array}$ & $\begin{array}{l}0 \\
12\end{array}$ & 0.017 \\
\hline Family history & $\begin{array}{l}\text { No } \\
\text { Yes }\end{array}$ & $\begin{array}{l}158 \\
4\end{array}$ & $\begin{array}{l}12 \\
0\end{array}$ & 1 \\
\hline Side & $\begin{array}{l}\text { Unilateral } \\
\text { Bilateral }\end{array}$ & $\begin{array}{l}147 \\
15\end{array}$ & $\begin{array}{l}10 \\
2\end{array}$ & 0.33 \\
\hline Palpable (191 testes) & $\begin{array}{l}\text { No } \\
\text { Yes }\end{array}$ & $\begin{array}{l}43 \\
133\end{array}$ & $\begin{array}{l}5 \\
10\end{array}$ & 0.53 \\
\hline Location (palpable I 43 testes) & $\begin{array}{l}\text { High scrotal } \\
\text { Canalicular } \\
\text { Unknown }\end{array}$ & $\begin{array}{l}20 \\
109 \\
5\end{array}$ & $\begin{array}{l}3 \\
6 \\
0\end{array}$ & 0.31 \\
\hline
\end{tabular}

between the two groups. Boys with hypospadias had significantly shorter gestational period and lower birth weight than those without hypospadias $(\mathrm{P}=0.0058$ and $\mathrm{P}=0.0006$, respectively). Boys with hypospadias were also incidentally diagnosed with cryptorchidism $(\mathrm{P}=0.017)$. Comparison of boys who underwent orchiopexy in both groups (boys without hypospadias, $n=150$; boys with hypospadias, $n=12$ ) showed that the age at orchiopexy was higher in boys with hypospadias than in those without hypospadias $(\mathrm{P}=0.028)$. In addition, boys without hypospadias had a higher rate of abnormality of the epidermis than those with hypospadias $(\mathrm{P}=0.024)$.

\section{Discussion}

This study summarizes our experience of treating boys with cryptorchidism, including the frequency and its chronological transition, at our institute for a period of 12 years. Orchiopexy performed at the mean age of 1 year. Vanishing testes were observed in 6 testes and orchiectomy was performed in 18 testes with nubbin. After orchiopexy, there was no testis re-elevation, and testicular atrophy was observed in 1 testis. A comparison of the characteristics between boys whose condition improved after orchiopexy and in whom the condition improved spontaneously showed that all cases of spontaneous improvement were diagnosed incidentally. In addition, a comparison of the characteristics between boys without hypospadias and boys with hypospadias revealed that boys with hypospadias tend to be born in a shorter gestational time, with low birth weight, and epididymis abnormalities.

Cryptorchidism is one of the most common diseases in pediatric urology, while the mechanism of development is still not completely understood, and the optimal timing of orchiopexy remains controversial. In Japan, orchiopexy is performed by the age of 2 years based on the recommendation of the Japanese guidelines for cryptorchidism. ${ }^{15}$ The European Association of Urology (EAU) guidelines 
Table 4 Comparison of Characteristics Between Cryptorchidism without Hypospadias and with Hypospadias $(n=184)$

\begin{tabular}{|c|c|c|c|c|}
\hline \multicolumn{2}{|l|}{ Variables } & \multicolumn{2}{|l|}{ Cryptorchidism } & \multirow[t]{3}{*}{$P$ value } \\
\hline & & \multirow{2}{*}{$\begin{array}{l}\text { Without Hypospadias } \\
\text { I7I }\end{array}$} & \multirow{2}{*}{$\begin{array}{l}\text { With Hypospadias } \\
13\end{array}$} & \\
\hline Number of patients & & & & \\
\hline Age at diagnosis (years) & Mean (range) & $2(0-9)$ & $2(0-4)$ & 0.36 \\
\hline Gestational age (weeks) & Mean (range) & $37(23-42)$ & $35(30-40)$ & 0.0058 \\
\hline Birth weight $(\mathrm{g})$ & Mean (range) & $2809(622-48 \mid 2)$ & I834 (660-3496) & 0.0006 \\
\hline Diagnostic opportunity & $\begin{array}{l}\text { Health examination for baby } \\
\text { Incidental }\end{array}$ & $\begin{array}{l}71 \\
100\end{array}$ & $\begin{array}{l}1 \\
12\end{array}$ & 0.017 \\
\hline Family history & $\begin{array}{l}\text { No } \\
\text { Yes }\end{array}$ & $\begin{array}{l}167 \\
4\end{array}$ & $\begin{array}{l}13 \\
0\end{array}$ & 1 \\
\hline Side & $\begin{array}{l}\text { Unilateral } \\
\text { Bilateral }\end{array}$ & $\begin{array}{l}154 \\
17\end{array}$ & $\begin{array}{l}10 \\
3\end{array}$ & 0.15 \\
\hline Palpable (204 testes) & $\begin{array}{l}\text { No } \\
\text { Yes }\end{array}$ & $\begin{array}{l}58 \\
130\end{array}$ & $\begin{array}{l}3 \\
13\end{array}$ & 0.4 \\
\hline Location (palpable 143 testes) & $\begin{array}{l}\text { High scrotal } \\
\text { Canalicular } \\
\text { Unknown }\end{array}$ & $\begin{array}{l}22 \\
102 \\
3\end{array}$ & $\begin{array}{l}1 \\
13 \\
2\end{array}$ & 0.072 \\
\hline Age at orchiopexy (years; $n=150$ vs $n=12$ ) & Mean (range) & I (0-9) & $2(0-4)$ & 0.028 \\
\hline Height at orchiopexy $(\mathrm{cm} ; \mathrm{n}=\mid 50$ vs $\mathrm{n}=\mid 2)$ & Mean (range) & $79.2(48.0-130.0)$ & $80.2(50.0-106.0)$ & 0.73 \\
\hline Weight at orchiopexy $(\mathrm{kg} ; \mathrm{n}=150$ vs $n=12)$ & Mean (range) & II.I (2.8-28.0) & II.2(6.0-17.8) & 0.87 \\
\hline $\begin{array}{l}\text { Abnormality of epididymis } \\
\text { (testes; } 162 \text { vs 15) }\end{array}$ & $\begin{array}{l}\text { No } \\
\text { Yes }\end{array}$ & $\begin{array}{l}118 \\
44\end{array}$ & $\begin{array}{l}15 \\
0\end{array}$ & 0.024 \\
\hline $\begin{array}{l}\text { Closure of processus vaginalis } \\
\text { (testes; } 162 \text { vs 15) }\end{array}$ & $\begin{array}{l}\text { No } \\
\text { Yes } \\
\text { Unknown }\end{array}$ & $\begin{array}{l}68 \\
23 \\
71\end{array}$ & $\begin{array}{l}4 \\
1 \\
10\end{array}$ & 0.23 \\
\hline $\begin{array}{l}\text { Testicular gubernaculum attachment } \\
\text { (testes; } 162 \text { vs 15) }\end{array}$ & $\begin{array}{l}\text { Upper scrotum } \\
\text { Inguinal canal }\end{array}$ & $\begin{array}{l}138 \\
24\end{array}$ & $\begin{array}{l}\text { II } \\
4\end{array}$ & 0.26 \\
\hline $\begin{array}{l}\text { Testicular atrophy after orchiopexy } \\
\text { (testes; } 162 \text { vs 15) }\end{array}$ & $\begin{array}{l}\text { No } \\
\text { Yes }\end{array}$ & $\begin{array}{l}160 \\
2\end{array}$ & $\begin{array}{l}14 \\
1\end{array}$ & 0.23 \\
\hline
\end{tabular}

recommend that any kind of treatment that consists of leading the testis to the bottom of the scrotum should be started at the age of 6 months and finished by the age of 12 months or at the latest, 18 months. $^{16}$ The American Urological
Association (AUA) guidelines also recommend that orchiopexy should be started at the age of 6 months and finished within the next year. ${ }^{17}$ The treatment is commonly initiated at 6 months of age. This is because cryptorchidism rarely 
descends after the age of 3 to 6 months, while spontaneous resolution is generally observed by the age of 6 months; therefore, careful follow-up is recommended by that period. $^{1,2}$ In this study, spontaneous improvement was observed in 12 cases, of which 5 (41.6\%) improved over the age of 12 months. Therefore, the criteria for decisionmaking for orchiopexy might still be controversial. Both the EAU and AUA guidelines recommend that orchiopexy should be performed at the latest by 18 months of age, and the EAU guideline is more rigorous by advocating that orchiopexy should be performed by the age of 12 months. A previous report also suggested that orchiopexy should be performed within the first year of life to protect fertility potential and no later than the age of 2 years in boys with palpable inguinal cryptorchid testes because of a progressive loss of germ cells and Leydig cells by histological analysis of cryptorchidism. ${ }^{18}$ Although the present study did not investigate fertility in adulthood, histological changes that cause testicular atrophy might not have occurred. The Japanese guidelines might strictly recommended an earlier timing for performing orchiopexy, but further evaluation is needed to establish an evidence in Japan.

With regard to the feature of orchiopexy in this study, $25 \%$ of cases that underwent orchiopexy were concomitant with abnormality of the epididymis. Favorito et al previously reported that anomalies of the epididymis were found in $35 \%$ of boys with cryptorchidism and in only $4 \%$ of normal fetuses. They also mentioned that disclosure of the processus vaginalis was observed in $58 \%$ of boys with cryptorchidism and in only $5 \%$ of fetuses. ${ }^{19}$ In this study, disclosure of the processus vaginalis was observed in at least $41 \%$ of boys. Barthold et al showed in their prospective study that a closed, partially closed, and open processus vaginalis was associated with an abnormality of the epididymis in $14 \%, 36 \%$, and $69 \%$ of boys, respectively, and abnormalities of the epididymis were more frequently associated with cryptorchidism (72\%) than with descended (34\%) testes. They concluded that a higher incidence of epididymal anomalies associated with disclosure of the processus vaginalis and androgenic stimulation might be required not only for closure of the processus vaginalis but also epididymal development. ${ }^{20}$ Kim et al also reported that epididymal abnormalities were observed more frequently when testis was located at proximal from the scrotum, including distal to the external inguinal ring, inguinal canal, and the abdomen. ${ }^{21}$ Although unclear mechanisms have been implicated in congenital diseases, deficiency in the androgen exposure might cause various phenotypes including cryptorchidism, abnormalities of epididymis, and disclosure of processus vaginalis.

With respect to deficient androgen exposure, cryptorchidism is closely correlated with hypospadias and known as a component of the testicular dysgenesis syndrome composed of cryptorchidism, hypospadias, testicular cancer, and low sperm quality. ${ }^{22,23}$ In this study, 13 boys (7\%) were diagnosed with cryptorchidism and hypospadias. Boys with hypospadias had a shorter gestational period, lower birth weight, and higher incidence of epididymal abnormalities than boys without hypospadias. Iwatsuki et al showed that testicular function in boys with both cryptorchidism and hypospadias is more severely impaired than that in boys with cryptorchidism or hypospadias, according to an analysis of serum hormones including luteinising hormone, follicle-stimulating hormone, and total testosterone. ${ }^{24}$ Therefore, boys with both cryptorchidism and hypospadias might need to undergo orchiopexy early to minimize the damage to the testis.

The present study has some limitations. The patient data were obtained retrospectively from a single institution, and the sample size was small. In boys with cryptorchidism, the evaluation and prevention of infertility and testicular cancer in adulthood are the most interesting and important issues. None of the boys developed testicular cancer, while we evaluated only boys who had available data in adulthood in this study. We could not evaluate infertility in this study. Further tracking investigation is needed to evaluate these paramount issues.

\section{Conclusion}

Our findings suggest that most boys with cryptorchidism are treated under the age of 2 years and the incidence of epididymal abnormality is relatively high, particularly in boys with hypospadias. Although cryptorchidism is one of the most common diseases in pediatric urology, the mechanism of its development is still not fully understood. Further research is warranted to develop an appropriate treatment timeline in boys with cryptorchidism.

\section{Acknowledgments}

The authors would like to thank all patients and their families who participated in this study for their important contributions. We also wish to thank Mariko Yoshimura (Department of Urology, Nara Medical University, Nara, Japan) for invaluable help with obtaining and summarizing the data used in this study. 


\section{Disclosure}

The authors report no conflicts of interest in this work.

\section{References}

1. Berkowitz GS, Lapinski RH, Dolgin SE, Gazella JG, Bodian CA, Holzman IR. Prevalence and natural history of cryptorchidism. Pediatrics. 1993;92(1):44-49.

2. Wenzler DL, Bloom DA, Park JM. What is the rate of spontaneous testicular descent in infants with cryptorchidism? J Urol. 2004;171(2 Pt 1):849-851. doi:10.1097/01.ju.0000106100.21225.d7

3. Ghirri $P$, Ciulli $C$, Vuerich $M$, et al. Incidence at birth and natural history of cryptorchidism: a study of 10,730 consecutive male infants. J Endocrinol Invest. 2002;25(8):709-715. doi:10.1007/ BF03345105

4. Bay K, Main KM, Toppari J, Skakkebæk NE. Testicular descent: INSL3, testosterone, genes and the intrauterine milieu. Nat Rev Urol. 2011;8(4):187-196. doi:10.1038/nrurol.2011.23

5. Hutson JM. Journal of Pediatric Surgery-Sponsored Fred McLoed Lecture. Undescended testis: the underlying mechanisms and the effects on germ cells that cause infertility and cancer. $J$ Pediatr Surg. 2013;48(5):903-908. doi:10.1016/j.jpedsurg.2013.02.001

6. Dave S, Liu K, Clark R, Garg AX, Shariff SZ. A retrospective population-based cohort study to evaluate the impact of an older sibling with undescended testis and hypospadias on the known maternal and fetal risk factors for undescended testis and hypospadias in Ontario, Canada, 1997-2007. J Pediatr Urol. 2019;15(1):41.e1-41. e9. doi:10.1016/j.jpurol.2018.09.021

7. Zakaria M, Azab S, El Baz M, Fawaz L, Bahagat A. Cryptorchidism in Egyptian neonates. J Pediatr Urol. 2013;9(6Pt A):815-819. doi:10.1016/j.jpurol.2012.10.024

8. Akre O, Lipworth L, Cnattingius S, Sparén P, Ekbom A. Risk factor patterns for cryptorchidism and hypospadias. Epidemiology. 1999;10 (4):364-369. doi:10.1097/00001648-199907000-00005

9. Gurney JK, McGlynn KA, Stanley J, et al. Risk factors for cryptorchidism. Nat Rev Urol. 2017;14(9):534-548. doi:10.1038/ nrurol.2017.90

10. Michikawa T, Matsufuji H, Araki Y, Nakamura A. Does early orchidopexy prevent morphological changes in undescended testes? A perioperative assessment using ultrasonography. Urol Int. 2008;81(2):210-214. doi:10.1159/000144063

11. Cendron M, Huff DS, Keating MA, Snyder HM $3^{\text {rd }}$, Duckett JW. Anatomical, morphological and volumetric analysis: a review of 759 cases of testicular maldescent. $J$ Urol. 1993;149(3):570-573. doi:10.1016/S0022-5347(17)36151-7
12. Hadziselimovic F, Herzog B. Importance of early postnatal germ cell maturation for fertility of cryptorchid males. Horm Res. 2001;55 (1):6-10.

13. Pike MC, Chilvers C, Peckham MJ. Effect of age at orchidopexy on risk of testicular cancer. Lancet. 1986;1(8492):1246-1248. doi:10.1016/S0140-6736(86)91389-9

14. Pettersson A, Richiardi L, Nordenskjold A, Kaijser M, Akre O. Age at surgery for undescended testis and risk of testicular cancer. $N \mathrm{Engl}$ $J$ Med. 2007;356(18):1835-1841. doi:10.1056/NEJMoa067588

15. Japanese Society of Pediatric Urology. Guideline for Cryptorchidism. Available from: https://jspu.jp/download/guideline/guideline_1.pdf. Accessed September 3, 2020.

16. European Association of Urology. Guideline for Pediatric Urology. Available from: https://uroweb.org/guideline/paediatric-urology/\#3. Accessed September 3, 2020.

17. American Urological Association. Guideline for Pediatric Urology. Available from: https://www.auanet.org/guidelines/cryptorchidismguideline\#x2578. Accessed September 3, 2020.

18. Park KH, Lee JH, Han JJ, Lee SD, Song SY. Histological evidences suggest recommending orchiopexy within the first year of life for children with unilateral inguinal cryptorchid testis. Int $J$ Urol. 2007;14(7):616-621. doi:10.1111/j.1442-2042.2007.01788.x

19. Favorito LA, Costa WS, Sampaio FJ. Analysis of anomalies of the epididymis and processus vaginalis in human fetuses and in patients with cryptorchidism treated and untreated with human chorionic gonadotrophin. BJU Int. 2006;98(4):854-857. doi:10.1111/j.1464410X.2006.06323.x

20. Barthold JS, Redman JF. Association of epididymal anomalies with patent processus vaginalis in hernia, hydrocele and cryptorchidism. J Urol. 1996;156(6):2054-2056. doi:10.1016/S0022-5347(01)65434$\mathrm{X}$

21. Kim SO, Na SW, Yu HS, Kwon D. Epididymal anomalies in boys with undescended testis or hydrocele: significance of testicular location. BMC Urol. 2015;15:108. doi:10.1186/s12894-015-0099-1

22. Wu WH, Chuang JH, Ting YC, Lee SY, Hsieh CS. Developmental anomalies and disabilities associated with hypospadias. J Urol. 2002;168(1):229-232. doi:10.1016/S0022-5347(05)64898-7

23. Skakkebaek NE, Rajpert-de Meyts E, Main KM. Testicular dysgenesis syndrome: an increasingly common developmental disorder with environmental aspects. Hum Reprod. 2001;16(5):972-978. doi:10.1093/humrep/16.5.972

24. Iwatsuki S, Kojima Y, Mizuno K, et al. Endocrine assessment of prepubertal boys with a history of cryptorchidism and/or hypospadias: a pilot study. $J$ Urol. 2011;185(6 Suppl):2444-2450. doi:10.1016/j.juro.2011.01.018
Research and Reports in Urology

\section{Publish your work in this journal}

Research and Reports in Urology is an international, peer-reviewed, open access journal publishing original research, reports, editorials, reviews and commentaries on all aspects of adult and pediatric urology in the clinic and laboratory including the following topics: Pathology, pathophysiology of urological disease; Investigation and treatment of urological disease; Pharmacology of drugs used for the treatment of urological disease. The manuscript management system is completely online and includes a very quick and fair peer-review system, which is all easy to use. Visit http://www.dovepress.com/ testimonials.php to read real quotes from published authors. 